\title{
Improving Air Quality with Solar Energy
}

Many states are seeking additional air pollution control strategies. Zero-emission solar technologies, such as solar electricity and solar water heating, can help air quality and energy officials in cities, states, and federal agencies improve air quality, achieve Clean Air Act goals, and reduce pollution control costs for both industry and taxpayers.

Solar technologies provide energy for heating, cooling, and lighting homes and heating water without any direct emissions; as a result, these technologies can help reduce air emissions and improve air quality. The use of solar energy systems on buildings displaces electricity generation from coal, natural gas, and oil power plants, which can reduce air pollutants such as nitrogen oxides, sulfur dioxide, and mercury; and greenhouse gas emissions such as carbon dioxide.

This fact sheet highlights two examples where solar technologies can help states meet regulatory requirements, and examines regulatory use (under cap and trade and state implementation plans) and voluntary use of the technologies to reduce air emissions.

\section{New Jersey Solar Incentives Help Reduce Emissions}

The state of New Jersey's Clean Energy Program helps reduce emissions by promoting use of clean energy technologies, including solar energy. The program promotes solar energy by providing strong state incentives for solar power purchases, including saving homeowners, businesses, and industrial facilities up to $60 \%$ on solar installations, low-interest loans for businesses and schools that use solar technologies, and grants for utility-scale projects. As of August 31, 2007, more than 2,351 solar energy systems have been installed statewide on residential, commercial, and public buildings. See the Renewable Energy section of the New Jersey Clean Energy Program Web site at www.njcep.com for more information.

A DOE pilot project worked to quantify displaced emissions from New Jersey's Clean Energy Program, including 1,505 MWh of generation from solar energy during the summer ozone season to displace an estimated 1.13 tons of nitrogen oxides (NOx). To prevent these emissions, New Jersey must also retire NOx allowances because it is within a NOx emissions "capand-trade" region. New Jersey has policies for its NOx emissions trading program that facilitate this - a renewable energy set-aside and provisions for aggregation of small projects to meet the minimum avoided emissions level to receive allowances. (For more on the state's activities, see www.nrel.gov/ docs/fy08osti/41173.pdf).

\section{Eastern States Using Solar to Help Meet Emissions Targets}

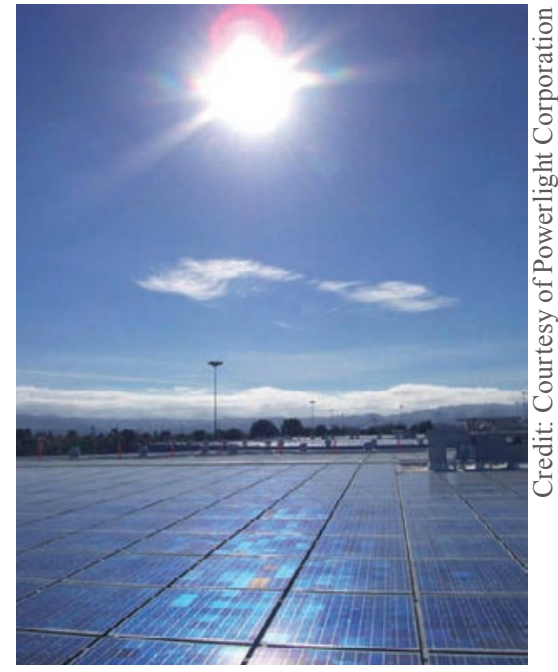

This 1.8-megawatt solar electric system on the Santa Rita Jail in Dublin, California, consists of three acres of solar photovoltaic panels that help reduce the use of the facility's utility-generated electricity by $30 \%$.

On March 2, 2007, nine states in the Ozone Transport Commission (the 12 states on the East Coast from Virginia to Maine, plus the District of Columbia) signed a memorandum of understanding (MOU) titled, "Among the States of the Ozone Transport Commission Concerning the Incorporation of High Electrical Demand Day (HEDD) Emission Reduction Strategies into Ozone Attainment SIP Implementation Planning." This MOU commits six of the states to pursue reductions in HEDD NOx emissions by 135 tons per day (total) by 2012 at the latest, and it includes measures to achieve these reductions in their 2007 ozone state implementation plans. Long term, the use of solar energy to help meet emissions reductions has the potential to substantially reduce the HEDD problem by providing customer-sited generation that coincides with high demand. 


\section{Solar Energy in Cap and Trade}

Some states have created opportunities for renewable energy (RE) and energy efficiency (EE) technologies, including solar electricity generation, to receive tradable allowances under state regulations that implement the federal Clean Air Interstate Rule. States that have done so - or are considering doing so-include Connecticut, the District of Columbia, Delaware, Illinois, Indiana, Massachusetts, Maryland, Michigan, Missouri, New Jersey, New York, Ohio, Pennsylvania, Virginia, and Wisconsin. In these states, solar projects can receive an additional income stream if they obtain and sell allowances. Alternatively, allowances from solar projects can be retired so that reductions of the capped pollutant, NOx, can be claimed. For more information and resources on cap-and-trade programs and RE technologies, please see "States Address Air Pollution from Energy through Energy Efficiency and Renewable Energy Programs" (www.nrel.gov/docs/fy08osti/42168.pdf).

\section{Solar Energy in State Implementation Plans (SIPS)}

States are using solar energy technologies to address air quality issues in their state implementation plans (SIPs). SIPs are U.S. Environmental Protection Agency (EPA)-approved plans for meeting clean air standards and associated Clean Air Act requirements. They include state-issued, EPA-approved control measures that target various air pollution sources, and planning documents such as area-specific compilations of emission estimates and computer simulations demonstrating air quality standards are met by states. The EPA offers guidance for using solar energy technologies and other renewables in SIPs. For more information and resources, see "States Address Air Pollution from Energy through Energy Efficiency and Renewable Energy Programs" (www.nrel.gov/docs/fy08osti/42168.pdf).

Following EPA guidance, states can take two new approaches to SIPs:

- Incorporating solar energy incentives as air emission reduction measures that target annual or seasonal emissions

- Incorporating solar energy incentives as SIP measures that target HEDD emissions.

Either way, the approaches above will probably be used in the special parts of a SIP that allow greater flexibility, such as the emerging and voluntary measures area, or a "weight-of-evidence" presentation. Quantification of emission effects is a key step for using solar energy as an emissions mitigation measure. Other fact sheets in this series describe some of the quantification methods that are being explored (see www.nrel.gov/docs/fy08osti/42164.pdf, www.nrel.gov/docs/fy08osti/42165.pdf, www.nrel.gov/docs/fy08osti/41173.pdf).

\section{Solar Energy in Supplemental Environmental Projects (SEPs)}

When a company violates environmental regulations, it must pay a fine to the state or federal government. The EPA designed supplemental environmental projects (SEPs) to give violators an alternative to standard fines. Instead of paying the full fine, a company can volunteer to fund environmentally friendly projects. These projects, which can be undertaken on either the federal or state level, can provide a positive outcome for the company and the community. Many different kinds of solar energy projects can be appropriate for SEPs, including solar heating, cooling, and lighting of public buildings or schools; water heating for public facilities; or purchase of renewable energy credits that support additional solar electricity development. For example, solar PV has been used in SEPs in Maryland and Colorado. EPA has released guidance for federal SEPs, while states are free to design and adopt their own approach to state SEPs. Most states have the authority to incorporate renewable energy into SEPs. For further information about using solar energy in SEPs, see EPA's SEP Toolkit at www.epa.gov/ cleanenergy/documents/sep_toolkit.pdf.

\section{Growing Opportunities}

Solar energy has many advantages: It emits little or no pollution during its use, uses little water, and often requires no construction of electric wires. Regulatory innovation has created the opportunity to use solar energy to help meet air quality standards. As solar energy's costs continue to decline and air quality standards become more stringent, it may become an even more attractive option for cities and states.

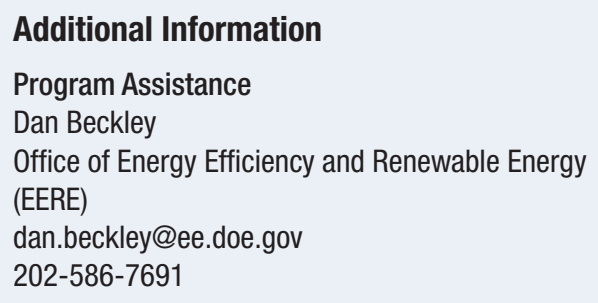

Technical Assistance Laura Vimmerstedt National Renewable Energy Laboratory (NREL) laura_vimmerstedt@nrel.gov 303-384-7346

NREL/FS-670-42169

DOE/G0-102008-2507, April 2008

\section{A Strong Energy Portfolio for a Strong America}

Energy efficiency and clean, renewable energy will mean a stronger economy, a cleaner

environment, and greater energy independence for America. Working with a wide array of state, community, industry, and university partners, the U.S. Department of Energy's Office of Energy Efficiency and Renewable Energy invests in a diverse portfolio of energy technologies. Energy by the National Renewable Energy Laboratory, a DOE national laboratory. Printed with a renewable-source ink on paper containing at least $50 \%$ wastepaper, including $20 \%$ postconsumer waste.
For more information contact: EERE Information Center 1-877-EERE-INF $(1-877-337-3463)$ www.eere.energy.gov 